Nordisk Tidsskrift for Kriminalvidenskab 2011

\title{
OM OBJEKTIVITETSPRINCIPEN I DEN POLISIÄRA VERKSAMHETEN \\ - UTKAST TILL PROBLEMSTÄLLNINGAR
}

Av Jur.dr., VH Johan Boucht

\section{Summary}

The objectivity principle is often seen as representing a fundamental value of the Rechtsstaat that is essential in all forms of state use of power. This article concerns objectivity in the exercise of police powers according to Finnish, Norwegian and Swedish law. In these legal orders, police powers are governed either by public law or criminal procedural rules depending on whether the tasks involve maintaining public order or investigating a crime. In the article, the content of the objectivity principle is explored from both perspectives. A discussion is included on whether the present understanding of the principle is sufficient as well as on possible forms of control of the police in this regard.*

\section{Inledning}

Polisrätten har traditionellt inte attraherat rättsvetenskaplig (rättsdogmatisk) forskning i någon större utsträckning. Anledningen till detta är inte helt klar. En delförklaring kan möjligen vara att polisrätten mest har ansetts innebära "ren tillämpning" snarare än att utgöra ett rättsområde kapabelt att ge upphov i intressanta forskningsfrågor; de rättsliga reglerna har helt enkelt ansetts så klara att några egentliga tolkningssvårigheter egentligen inte kunnat uppkomma. Möjligen kan det också ha något att göra med att polisrättsliga frågeställningar ofta ligger mellan flera rättsområden, t.ex. förvaltningsrätt, straffprocessrätt och straffrätt, vilket kan bidra till att forskare från de olika rättsområdena undvikit frågeställningarna.

Oberoende av hur det egentligen ligger till med detta kan man emellertid notera att polisrätten under det senaste decenniet har kommit att attrahera en allt större mängd rättsvetenskaplig (och medial) uppmärksamhet. Detta är något som får värderas positivt, eftersom den polisiära verksamheten (särskilt befogenhetsområdet), som en konkretisering av det statliga maktmonopolet, ständigt bör underställas diskussion och analys. ${ }^{1}$ Detta har att göra med de förväntningar på bl.a. rättssäkerhet och rättsskydd, som den enskilde bör anses kunna ha i en demokratisk rättsstat. Samtidigt förefaller det intresse som förekommit i första hand ha riktat in sig på den mer konkreta befogenhetsutövningen, t.ex. våldsanvändning eller hemliga spaningsmetoder. ${ }^{2}$ Andra områden, som i sig besitter samma indivi-

\footnotetext{
* Title in English: The Objectivity Principle in Police Work - an Outline of Problem Formulations.
} 
dualsfärskränkande potential, har istället ofta, medvetet eller omedvetet, lämnats utanför diskussionen. En sådan fundamental frågeställning berör kravet på objektivitet i den polisiära verksamheten.

Objektivitet i den statliga maktutövningen får anses utgöra ett av rättsstatens fundamentala värden. Kravet på objektivitet avser sålunda en grundläggande rättslig problemställning i gränslandet mellan polis, åklagare och domstol, som är central för bl.a. förverkligandet av straffrättens funktioner. Även om det i doktrinen råder enighet om att en objektivitetsprincip, eller ett objektivitetskrav, ${ }^{3}$ är central( $(\mathrm{t})$ för polisens verksamhet, har dess konkretisering och betydelse inom ramen för polisarbetet inte berörts i någon närmare utsträckning. Det föreligger därför enligt min mening ett tomrum beträffande denna för den statliga maktutövningens legitimitet fundamentala premiss.

I detta bidrag är syftet att reflektera över denna problematik och skissera hur ett forskningsprojekt på detta område kunde se ut. Ett sätt att fylla nämnda tomrum vore att diskutera frågeställningen $\mathrm{i}$ ett nordiskt komparativt perspektiv. En sådan komparativ nordisk forskningsapproach framstår som fruktbar av flera skäl. De nordiska samhällena är relativt homogena och bygger på liknande politiska, sociala och kulturella värderingar. ${ }^{4}$ Det föreligger betydande likheter i konceptionen av det sätt på vilket polisen agerar och förväntas agera i samhället, men även bl.a. i tillämpningen av de fundamentala rättssäkerhetsgarantier som gäller i straffprocessen. Samtidigt som likheter mellan länderna föreligger har varje land ändå valt att delvis hantera objektivitetsproblematiken på ett eget sätt, vilket ger ett gott underlag för komparation. I detta sammanhang kommer frågan att beröras utifrån finsk, norsk och svensk rätt. ${ }^{5}$

Frågeställningar att adressera är, primo, objektivitetsprincipens rättsliga innehåll och hur kravet på objektivitet kan och bör konkretiseras inom polisrätten. Denna problematik konkretiseras i två "spår": dels i förhållande till det preventiva polisarbetet, dels i förhållande till den repressiva förundersökande verksamheten. Principen är lika viktig på bägge områdena, men synes prima facie ändå erhålla särskild betydelse på det repressiva området. ${ }^{6}$ På grund av perspektivens interaktion med varandra bör ändå bägge dimensionerna undersökas.

Secundo, och nära kopplad till det förra, ligger frågan om vilka mekanismer som existerar, eller bör konstrueras, i syfte att trygga objektivitetens existens och tillgodoseende i den praktiska polisiära verksamheten, och därigenom även tillhandahållandet av rättssäkerhet, i den praktiska polisiära verksamheten. En elaborerad konception av principens innehåll är helt enkelt inte tillräcklig om det inte samtidigt existerar mekanismer genom vilka dess konkreta förverkligande kan övervakas. Tertio, och även denna kopplad till de två tidigare frågeställningarna, ligger frågan hur utredningen av misstänkta överträdelser av polismän bör 
utföras utifrån ett objektivitetsperspektiv. Som en följd av dess relevans för helheten berörs denna frågeställning helt kort i slutet.

\section{Objektivitetsprincipens praktiska och samhälleliga betydelse}

Polisen representerar en konkret och synlig form av det statliga maktmonopolet och som en följd härav har polisiär aktivitet ofta bäring direkt på enskildas individualsfärer. Redan häri ligger ett starkt skäl för att granska gränserna för utövandet av de polisiära befogenheterna. Samtidigt bör de polisiära effektivitetshänsynen beaktas. Fråga är sålunda om att träffa en rimlig balans mellan dessa perspektiv.

Från senare år hittas från Finland, Norge och Sverige ett antal rättsfall som framhäver nödvändigheten av att den (straffprocessuella) objektivitetsprincipen följs, men även att kontrollmekanismer i detta hänseende utvecklas. De visar på betydelsen och behovet av objektivitet i förundersökningen, liksom i den polisiära verksamheten generellt. Rättsfallen visar vilka typer av brister i förundersökningen, med direkta kopplingar till objektivitetsprincipen, som kan förekomma; inom rådande rättssystem hade dessa dock i flera fall troligen varit svåra att undanröja. Indirekt framhävs sålunda behovet av forskning på området. ${ }^{7}$ Innan själva forskningsprojektets innehåll skisseras är det därför motiverat att $i$ korthet redogöra för dessa fall, inte minst som en konkretisering av objektivitetsprincipens centrala praktiska betydelse.

1) Fritz Moen-fallet (Norge). I september 1978 hittades de två kvinnliga studenterna A och B döda; A genom strypning och B genom drunkning. På grund av likheterna mellan dråpen antog polisen att det rörde sig om samma gärningsman. Fritz Moen, en döv man med stora sociala och kommunikationsmässiga svårigheter, greps något senare såsom misstänkt för morden. I polisförhören medgav Moen inledningsvis att han dödat $\mathrm{B}$, men växlade senare mellan att ibland förneka och ibland medge mordet. Han gav härvidlag även uttryck för omständigheter som inte överensstämde med de fynd som polisen gjort. Moen kom även att misstänkas för mordet på A, men han medgav inte detta. Även under huvudförhandlingen beträffande mordet på $\mathrm{B}$ pendlade Moen mellan att medge gärningen och att förklara sig själv oskyldig. Han dömdes 1978 för mordet på B till 16 års fängelse. 1981 åtalades Moen även för mordet på A. Även under denna huvudförhandling pendlade han mellan att berätta detaljer om mordet och hävda sin skuldfrihet. Moen dömdes för mordet på A till ytterligare fem års fängelse.

År 2004 beviljades resning för mordet på A och Moen frikändes. Han ansökte om resning även för mordet på B, men avled själv under denna process. År 2006 återupptogs ärendet till prövning och Moen friades även för mordet på $\mathrm{B}$ efter att en man år 2005 strax före sin död erkänt morden på både A och B. Senare tillsattes en kommitté för att granska Moen-fallet. ${ }^{8}$ Kommittén, som gjorde ett antal kritiska 
anmärkningar mot bl.a. förundersökningen, ansåg att kravet på objektivitet hade brustit i förundersökningen, eftersom bevis som kunde ha etablerat rimliga tvivel mot Moens erkännande inte hade undersökts närmare. Bland annat hade ulltrådar, som inte funnits med i listan över säkrade material, hittats. Vissa upplysningar som Moen hade gett under förhören hade inte heller nedtecknats och protokoll hade dokumenterats felaktigt. ${ }^{9}$ Kommittén pekade på att polisen i flera fall inte varit tillräckligt objektiv i sin utredning eller tillräckligt kritisk till Moens erkännanden. Man menade sig ha identifierat exempel på att Moen utsatts för press under förhöret, att vittnen utsatts för press för att de skulle berätta det som polisen ville höra, att bevis som talat till den tilltalades fördel undertryckts eller bortsetts från och att dokument som talat för Moens skuldfrihet fătts att försvinna från utredningen. ${ }^{10}$ Kommittén pekade även på problem vid utnämningen av expertvittnen. ${ }^{11}$ Man fann att de flesta överträdelserna mot objektivitetsprincipen betraktade isolerat förvisso inte varit grova, men att de tillsammans kan ha haft stor betydelse. ${ }^{12}$

2) Thomas Quick-fallet (Sverige). ${ }^{13}$ Thomas Quick dömdes 1994-2001 för åtta mord begångna under åren 1976-1988. Quick erkände samtliga mord. ${ }^{14}$ Han återtog emellertid samtliga erkännanden i en TV-dokumentär hösten 2008 och under år 2009 inlämnade Quick flera resningsansökningar. Resning beviljades i flera fall och Quick friades. Svea HovR lyfte t.ex. i resningsbeslutet Ö 3147-09 fram att det fanns nya bevis, samt att tingsrättens beslutsunderlag varit begränsat p.g.a. Quicks erkännande och att det funnits flera omständigheter som tingsrätten inte vetat om, men som troligen hade kunnat påverka domen. Enligt Quicks advokat hade i Rikskriminalpolisens arkiv hittats bevis som talade för Quicks skuldfrihet i mordet av en norsk kvinna i Norge 1988. Enligt dokumentet hade Quick arbetat i en kiosk på annan ort samma kväll som offret fördes bort. Denna omständighet framgick även av en promemoria skriven av en utredare i fallet. Handlingarna förekom dock aldrig i utredningen. I resningsansökan avseende mordet på en israelisk turist pekades bl.a. på brister i utvärderingen av de två rekonstruktioner som gjordes. Utvärderingen av den första resulterade i att Quicks uppgifter inte stämde med de kriminaltekniska fynden, medan det vid den andra slogs fast att inget konkret i den kriminaltekniska utredningen stödde Quicks uppgifter. Ingen av de gjorda utvärderingarna togs dock med i förundersökningen och redovisades inte heller för tingsrätten. Det har påståtts att Quicks erkännanden berott på medicinering och behov av uppmärksamhet. ${ }^{15}$

4) Kaj Linna-fallet (Sverige). Den 14 april 2004 angreps två bröder, 59 och 57 år gamla, på sin gård i byn Kalamark två mil väster om Piteå, Sverige. Den äldre brodern slogs ner med en påk och bakbands i ladugården, medan den yngre, som var handikappad, överfölls när han låg i sin säng och fick då ett slag i huvudet och bakbands. Bröderna hittades två dagar senare av hemtjänsten; brodern i ladugår- 
den var död medan den andre överlevde. Kaj Linna greps sommaren 2004 och dömdes 2005 mot sitt nekande för rån, mord och mordförsök till livstids fängelse. Det fanns varken teknisk bevisning eller något vittne som kunde binda honom till brottsplatsen. Avgörande blev istället ett vittne som påstod att Linna hade talat om att göra en stöt hos bröderna och hävdade att han dagen före mordet hade åkt tillsammans med Linna till Kalamark.

Dagstidningen Dagens Nyheter (DN) genomförde ett självständigt utredningsarbete i saken. Enligt DN, som anlitade externa sakkunniga, hade det gjorts flera fel i polisutredningen. Vid brottsplatsundersökningen hittades en snusprilla ur vilken Statens Kriminaltekniska Laboratorium (SKL) kunde isolera en DNA-profil. DNA-profilen matchade enligt chefsåklagaren dock inte någon som var aktuell i målet och avfördes därför. ${ }^{16}$ SKL-protokollet bifogades aldrig utredningen, inte vare sig förundersökningsprotokollet eller den s.k. slasken, utan förvarades istället på tekniska roteln hos polisen i Norrbotten. ${ }^{17}$

Ett centralt bevis under rättegången var ett vittne som påstod att Linna hade talat om att göra "en stöt" hos bröderna och som påstod sig hade åkt med Linna till Kalamark dagen före mordet. Enligt DN hade polisen inte närmare kontrollerat uppgifterna. ${ }^{18}$ Vid tiden för den s.k. avvärjningsresan hade två samtal ringts från vittnets mobiltelefon, vilka kopplades upp mot två mobilmaster i Piteå och Öjebyn, som ligger cirka 20 kilometer från Kalamark. Vittnet förnekade dessa samtal och menade att hans mobil låg på laddning i en annan bil som hans far använde i Piteå och att mobilen därför av skakningarna råkat knappa in det senast slagna numret. Enligt DN tillhörde emellertid inget av de uppringda numren de senast slagna. Uppgifterna kontrollerades aldrig av polisen, eftersom uppgifterna enligt åklagaren kommit fram sent under rättegången. DN lät utföra mätningar som visade att de två master som vittnets mobiltelefon kopplat upp sig emot i första hand täckte centrala Piteå och Öjebyn. Uppkopplingsuppgifterna indikerade därför enligt DN att vittnet befann sig i centrala Piteå eller dess närhet vid den tidpunkt då han enligt vittnesmålet reste med Linna till Kalamark och att vittnets utsaga om avvärjningsresan därför inte varit korrekt.

DN noterade även skeendena efter händelsen i Kalamark när Linna lämnade Norrbotten för en resa till Amsterdam och London. Han blev då rånad på pengar och mobiltelefon i Amsterdam. Polisen ansåg att fråga var om flyktförsök och att berättelsen om rånet inte var trovärdig. Linna hade däremot enligt egen utsago begärt pengar av en kvinnlig bekant i Storbritannien för att kunna fortsätta resan. Kvinnan avgav vittnesmål åt den brittiska polisen, hvilket bekräftade Linnas berättelse. Trots att den brittiska polisen arbetade på uppdrag av den svenska polisen fanns inga uppgifter om vittnets berättelse i utredningen.

Åbo-rånet (Finland). 1994 rånade två personer, varav den ena var beväpnad, 
ett bankkontor i Åbo. Senare hittades på olika ställen i Åbo kläder som rånarna hade haft på sig under rånet. $\mathrm{F}$ misstänktes efter vittnesmål av några fångvaktare som i tjänsten haft kontakt med F. V misstänktes, eftersom en brottskumpan söktes åt $\mathrm{F}$ och det hade visat sig att $\mathrm{F}$ och $\mathrm{V}$ blivit bekanta i Helsingfors länsfängelse. $\mathrm{F}$ troddes vara den beväpnade rånaren och $\mathrm{V}$ den som hoppade över bankdisken. F greps av andra skäl i Åbo kort efter rånet och hade då 20 gram amfetamin i sin besittning. $\mathrm{V}$ greps i Helsingfors en knapp månad efter rånet. $\mathrm{F}$ och $\mathrm{V}$ dömdes $\mathrm{i}$ tingsrätten 1995, i vars dom hovrätten förenade sig, för grovt rån till tre års ovillkorligt fängelse. Högsta domstolen beviljade inte prövningstillstånd.

År 1998 tog den estniske medborgaren, som satt i fängelse i Pärnu, kontakt med polisen i Åbo och erkände rånet. ${ }^{19}$ Som en konsekvens härav återbröt Högsta domstolen domen år 2002 för V:s del och återförvisade ärendet till tingsrätten, som senare ogillade åtalet. Tingsrättens dom överklagades inte. Domen återbröts inte för F:s del och F dog senare.

Ärendet kom att granskas av en inofficiell arbetsgrupp, som var kritisk till flera moment i processen. Det påpekades för det första, att det ur materialet inte framgick att någon teknisk brottsplatsundersökning hade gjorts på brottsplatsen. Enligt arbetsgruppen var det förvisso möjligt att sådan undersökning hade utförts, men att protokoll däröver inte upprättats eller inte har fogats till förundersökningsmaterialet. I vilket fall var det fråga om en allvarlig brist. Om undersökningen däremot inte alls hade utförts vore det enligt gruppen en enastående underlåtelse. Det framgick även att polisen vid tagande av fiberprov från de klädesplagg som använts vid rånet hade iklätt den misstänkte samma kläder för fotografering, men att detta skett innan provtagningen utförts. Kontamination av bevisningen hade sålunda skett. Då detta sattes i sammanhang med den stora tillit som domstolarna i Finland vedertaget tillmätte teknisk bevisning blev saken problematisk. Även vittnenas och målsägandenas konfrontation med, dvs. identifiering av, de misstänkta var enligt arbetsgruppen otillförlitlig och utförd med dåligt professionellt kunnande. Bland annat hade fotografier på den misstänkta visats före konfrontationen. ${ }^{20}$ Härutöver hade tre förhör med målsäganden och vittnen inte fogats till förundersökningsprotokollet. I vissa av förhören uttrycktes tvivel om särskilt V:s delaktighet i rånet. Förhören hittades 2004. I den undersökning om skälet till försvinnanden som utfördes kunde inte pekas på någon särskild orsak till underlåtelsen. Polismannen som utförde förhören avled 1998.

\section{Närmare om objektivitetsprincipen som problemställning}

\subsection{Objektivitetsprincipens innehåll och rättsliga position}

Som en följd av de krav på bl.a. rättssäkerhet ${ }^{21}$ som följde på Upplysningen skapades olika kontrollmekanismer för straffprocessen. Två viktiga utgångspunkter, 
som bägge syftar till att förhindra godtyckliga domslut, är legalitetsprincipen och oskuldspresumtionen. Dessa principer har under åren kommit att representera kärnan i ambitionerna att åstadkomma rättssäkerhet i straffprocessen. Den förstnämnda är ett materiellt krav, som skall garantera att straffrättslig skuld endast kan etableras utifrån existerande och tillräckligt precis lagstiftning. ${ }^{22}$ Den senare är processuell och uppställer bl.a. en bevisbördeprincip: till dess att tillräcklig bevisning beträffande den misstänktes skuld har uppställts av åklagaren skall han behandlas som oskyldig. ${ }^{23}$ Objektivitetsprincipen uppställer i förundersökningen bl.a. krav på opartiskhet och saklighet från de undersökande myndigheternas sida och är ett viktigt komplement till oskuldspresumtionen.

Objektivitetsprincipens två dimensioner kan sägas skilja sig från varandra såtillvida att opartiskheten är objektiv till sin karaktär, dvs. avser den yttre relationen mellan den som utövar makt (beslutsfattaren) och objektet för maktutövningen. ${ }^{24}$ Det relevanta är här hur beslutsfattandet ter sig utåt. Saklighet, å andra sidan, åsyftar de faktorer som ligger till grund för maktutövningen och förutsätter att dessa skäl inte är ovidkommande för tjänsteåtgärden, t.ex. så att beslutsfattandet bygger på subjektiva överväganden. Utan ett korresponderande krav på objektivitet under förundersökningen skulle bl.a. de skyddsmekanismer som oskuldspresumtionen uppställer kunna komma att undermineras. Detta kan vara fallet om den förundersökande myndigheten skulle beakta subjektiva fördomar om t.ex. vissa folkgruppers benägenhet att begå brott och lägga dem till grund för sin övertygelse om gärningsmannens skuld (se även avsnitt 2 för konkreta exempel).

Ambitionerna att utveckla mekanismer för att binda domaren i straffprocessen har emellertid, trots objektivitetsprincipens centrala betydelse, aldrig riktigt matchats av liknande ambitioner att binda den förundersökande myndigheten. Det råder förvisso enighet $\mathrm{i}$ doktrinen om behovet av ett objektivitetskrav, men innehållet i detta och hur det bör realiseras har inte varit föremål för någon närmare analys, vare sig beträffande den repressiva eller för den preventiva polisiära verksamheten. Som en konsekvens härav existerar i dag få mekanismer genom vilka upprätthållandet av objektivitet i t.ex. straffprocessens undersökande fas kan kontrolleras. Detta gäller dock inte endast i polisens s.k. repressiva aktivitet, utan även i den preventiva polisiära verksamheten, dvs. den verksamhet som bedrivs med stöd av offentligrättsliga befogenhetsnormer.

Såsom framgick ovan är kravet på objektivitet centralt både i den repressiva och i den preventiva polisiära verksamheten. Lagbestämmelser om objektivitetsprincipen $\mathrm{i}$ den repressiva polisverksamheten existerar $\mathrm{i}$ alla de rättsordningar som här är föremål för jämförelse. I finsk rätt återfinns bestämmelsen i förundersökningslagen (1987/449) 7 §, i norsk rätt i straffeprosessloven (1981-05-22-25) § 226 och i svensk rätt i rättegångsbalken (1942:740) 2:1.25 
Objektivitetsprincipen anses i den straffprocessuella kontexten innebära en skyldighet för utredarna att beakta både omständigheter som talar för och emot den misstänkte. ${ }^{26}$ Principen kan därmed betraktas som en sorts gyllene tumregel som syftar till utredande av den materiella sanningen på ett adekvat och tillfredställande sätt. ${ }^{27}$ Upprätthållande av objektivitet i förundersökningen knyter således an till ambitionerna att utröna sanningen $i$ ärendet, både under förundersökningen och i domstolsprocessen..$^{28}$ Det bör påpekas att utgångspunkten vid förundersökningen är att undersöka brottet, inte att slå fast gärningsmannens skuld. Kravet på objektivitet påverkar inte endast skyldigheten att bedriva förundersökning (den s.k. formella legalitetsprincipen ${ }^{29}$ ), utan även tolkningen av de bevis som inhämtats. När t.ex. trovärdigheten i ett medgivande värderas måste uppmärksamheten riktas inte endast på omständigheter som styrker medgivandet, utan också på de omständigheter som talar emot det. ${ }^{30}$ Samma bör gälla när parter och vittnen hörs; undersökaren får inte låta förhöret och de frågor som ställs påverkas av bl.a. hans subjektiva uppfattning. ${ }^{31}$

Också beträffande den preventiva polisverksamheten är kravet på objektivitet lagfäst i alla de rättsordningar som är föremål för jämförelsen: i Finland i polislagen (1995/493) 2,1 § och i Norge i politiloven (1995-08-04-53) §6. ${ }^{32}$ I Sverige saknas i polislagen (1984:387) förvisso en explicit bestämmelse om kravet på objektivitet. Det föreligger dock inget tvivel om att objektivitetsprincipen ändå gäller. Kravet på objektivitet härleds istället från det allmänna förvaltningsrättsliga objektivitetskravet i RF 1:9 som gäller all svensk förvaltningsrätt: "[d]omstolar samt förvaltningsmyndigheter och andra som fullgör uppgifter inom den offentliga förvaltningen skall i sin verksamhet beakta allas likhet inför lagen samt iakttaga saklighet och opartiskhet". ${ }^{33}$ Polisen, som en del av de statliga förvaltningsmyndigheterna, omfattas därigenom indirekt av detta krav beträffande all sin myndighetsverksamhet.

Enligt doktrinen innebär objektivitetskravet i detta sammanhang att en polisman när han utövar sina lagliga befogenheter inte får beakta vare sig omständigheter som är oförenliga med syftet med den lagbestämmelse som han avser att verkställa eller med den åtgärd som han avser att utföra (s.k. objektivt maktmissbruk), eller omständigheter av subjektiv karaktär (s.k. subjektivt maktmissbruk). I den preventiva, eller ordningsupprätthållande, verksamheten är objektivitetsprincipen central i hela verksamheten. Som ett exempel på när den kan komma att aktualiseras kan nämnas den situationen att polisen utför trafikkontroll. Eftersom alla bilar i en sådan kontroll inte kan stoppas, eller alla stoppade förare tilldelas inte bot eller varning, uppstår fråga om på vilka grunder som urvalet har gjorts. Samma gäller vid t.ex. omhändertaganden av person(er) vid ordningsstörande verksamhet. Om flera personer bedriver ordningsstörande verksamhet kan fråga uppstå varför t.ex. 
endast en viss person omhändertas medan de övriga däremot inte utsätts för något polisiärt ingripande.

Det kan hävdas att den uppfattning om objektivitetskravets innebörd som förekommer i litteraturen och som hittills redovisats är något för snäv. Det kan t.ex. knappast separeras så klart mellan å ena sidan den preventiva polisiära verksamheten och å andra sidan repressiva polisiära verksamheten. Istället synes t.ex. den repressiva objektivitetsprincipen också innefatta krav på opartiskhet, saklighet och jämställdhet, dvs. vara avhängig av den förvaltningsrättsliga objektivitetsprincipen. Även om polismän utför straffprocessuella åtgärder är polismän fortfarande tjänstemän och omfattas därmed hela tiden av den förvaltningsrättsliga polisiära objektivitetsprincipen. Man kan därför kanske säga att den straffprocessuella objektivitetsprincipen i dessa fall kompletterar den förvaltningsrättsliga och tillför extra krav. Denna dimension pekar även på interaktionen mellan det preventiva och det repressiva polisiära perspektivet. ${ }^{34}$

Det kan vidare hävdas, att det faktum att tröskeln för misstanke i förhållande till en socialt abnorm person ofta är lägre än i förhållande till en "normal" person kan betraktas i ljuset av människans bristfälliga natur. Men det kan däremot knappast vara acceptabelt för statsapparaten att utgå från samma premisser. Trots detta kan överträdelser av objektivitetskravet ofta kopplas till just misstankar mot personer med låg social status, onormalt beteende eller en bakgrund av social deviation. Detta fenomen kan iakttas under hela den straffrättsliga historien. Det är emellertid en central utgångspunkt i en demokratisk rättsstat, liksom i den nordiska välfärdsstaten, att också, eller kanske just särskilt, sådana personer bör ha rätt till rättsligt skydd och skydd mot statligt maktmissbruk. Liknande resonemang kan föras även gällande t.ex. social status eller ålder. Man kan alltså fråga sig huruvida personer med olika social status eller olika ålder behandlas på samma sätt av polisen? ${ }^{35}$ Även frågor beträffande kön är relevanta i dessa sammanhang. Behandlas t.ex. två personer av olika kön på likartat sätt i en likartad situation?

Art. 6 om var och ens rätt till rättvis rättegång i Europeiska konventionen om skydd för de mänskliga rättigheterna och de grundläggande friheterna synes kunna bli relevant i förhållande till objektivitetsproblematiken, även om dess betydelse i detta hänseende sällan verkar ha diskuterats. En viktig dimension är nämligen informationens transparens, eller genomskinlighet, dvs. att all den information som inhämtas under efterforskningen också bör redovisas till parterna. ${ }^{36}$

Två områden inom förundersökningen där objektivitetskravet är av stor betydelse och där brister kan ha betydande konsekvenser är dels s.k. ögonvittnesidentifiering (konfrontation), dels användningen av sakkunnigvittnen. I doktrinen har t.ex. ansetts att problem i den process som omger ögonvittnesidentifieringen är en central anledning till felaktiga domar. ${ }^{37}$ Sakkunnigvittnen används både i förun- 
dersökningen och under domstolsbehandlingen på områden som ballistik, toxikologi, rättsmedicin, (forensisk) psykologi osv. för att tillhandahålla nödvändig information om bl.a. olika faktiska förhållanden till förundersökningsmyndigheten och domstolen. Beträffande sakkunnigvittnen är t.ex. utnämnandet av vittnena ett särskilt problemområde. Som exempel kan nämnas det faktum att ett vittne som utnämnts av polisen sällan är jävigt att fortsätta som domstolsutnämnd expert, även om det härigenom skapas ett problematiskt förhållande mellan polisen/ åklagaren och expertvittnet. ${ }^{38}$ Det kan nämnas att Moen-kommissionen var högst kritisk till de norska reglerna i fråga och rekommenderade ändringar. Den föreslog att ett sätt att avlägsna den nämnda kopplingen vore att diskvalificera en expert som har använts av polisen från att bli utnämnd av domstolen eller att skapa en separat myndighet, som efter att ha fått information från polisen om deras behov, skulle överväga vilken expert som vore lämpad att anta uppgiften. ${ }^{39}$

Beträffande den preventiva verksamheten uppstår åter frågan om vilka parametrar som bör tillmätas relevans vid bedömningen av olika ingripanden. Entydigt är att alla fall inte kan behandlas lika i alla situationer, dvs. likhetsprincipen kan inte vara absolut, men olikbehandling måste kunna motiveras rationellt. Fråga uppstår följaktligen dels om huruvida relevanta parametrar låter sig formuleras in abstracto om när man skall kunna anse att ett visst beslut är sakligt motiverat, dels, och om den förra frågan besvaras jakande, vilka dessa parametrar är.

\subsection{Vissa övriga näraliggande frågeställningar}

Vid sidan av objektivitetsprincipens rättsdogmatiska innehåll inom de två polisiära spåren är, såsom ovan påpekats, en viktig pendang till denna problematik frågan om kontrollmekanismer för upprätthållande av objektivitet i praktiken. Oklarheter synes nämligen inte endast gälla innehållet i och formuleringen av objektivitetskravet, utan även den mera praktiska frågan om hur objektivitetskravets förverkligas och upprätthållande i det praktiska polisarbetet kan kontrolleras. Man kan kanske säga att fråga här är om en från "traditionell" jurisprudens något avvikande frågeställning. Utgångspunkten är att det föreligger en betydande risk för att polismän kan underlåta att ta frågan om objektivitet tillräckligt allvarligt i vissa situationer om adekrata kontrollmekanismer inte existerar. Även om presumtionen givetvis är att kravet på objektivitet respekteras är det istället möjligheten för en polisman att kunna bortse från kravet, utan att det nödvändigtvis uppdagas, som är relevant för denna frågeställning. Det är helt enkelt inte tillräckligt att en rättsordning innehåller en elaborerad konception av objektivitetsprincipen de lege lata om systemet saknar kontrollmekanismer för dess efterföljande.

Kärnan i problematiken är att det i dag existerar få mekanismer som, bortsett från i exceptionella situationer ex post, är kapabla att synliggöra event uella ob- 
jektivitetsbrister såväl under förundersökningen som under polisarbetet generellt; brister som i värsta fall kan leda till allvarliga justitiefel ${ }^{40}$ En konsekvens härav är att sådana fel är så gott som omöjliga att upptäcka från "utsidan". Man bör därför fråga sig huruvida, och i så fall hur, mekanismer kunde skapas genom vilka upprätthållandet av objektivitet i den vardagliga polisiära verksamheten kunde upprätthållas och tryggas. Hur kan man t.ex. trygga att centralt bevismaterial som hittas på en brottsplats också redovisas för parterna (se Linna-fallet ovan)? I t.ex. svensk rätt finns förvisso ett system med en s.k. slask dit allt förundersökningsmaterial skall läggas och dit parterna har tillgång, men samtidigt verkar det inte finnas någon egentlig kontroll av vad som verkligen läggs i "slasken". Vore det sålunda t.ex. möjligt att utveckla dokumentationsrutiner som säkerställer att information som insamlats under undersökningen också redovisas för parterna in toto och att handlingar inte försvinner under processen (se t.ex. det s.k. Åbo-rånet ovan). Här kan nämnas ambitionen i Finland att skapa en datasystemshelhet för åklagarväsendet och de allmänna domstolarna i syfte att effektivisera och samordna ärende- och dokumenthanteringsprocesserna och möjliggöra tväradministrativt elektroniskt samarbete med andra myndigheter. ${ }^{41}$ Meningen är att för ärende- och dokumenthanteringen skapa en databas som innehåller polisens elektroniska förundersökningsmaterial och där det är möjligt att producera och hantera rättegångsmaterial som hänför sig till ärendena. Alla parter i en rättegång skall då kunna utnyttja materialet som samlats i databasen och tillgången till informationen skall styras genom ärendets behandlingsfas, instansen som behandlar ärendet samt användarens behörighet och roll.

En viktig omständighet vad gäller upprätthållandet av de krav som objektivitetsprincipen ställer synes även vara förvaltningskulturen i myndigheten, dvs. här inom polisen, och vilken strävan efter självkontroll som eftersträvas inom myndigheten. I detta avseende spelar polisutbildningen en central roll. Samtidigt gäller förstås att total kontroll aldrig kan uppnås. Kontrollen kommer sålunda alltid delvis att retrospektivt förverkligas genom de arbetsrättsliga och straffrättsliga tjänsteansvarsreglerna.

En andra viktig pendang är frågan om upprätthållandet av objektivitet vid undersökningen av misstänkta fel som begåtts av polismän i tjänsten. Särskilt i dessa fall aktualiseras den gamla sentensen: rättvisa måste inte bara skipas, det måste också se ut som att den skipas. Enligt gällande svensk och finsk rätt undersöks sådana misstankar i utgångspunkten av polisen själv. I Finland agerar dock alltid åklagare som förundersökningsledare i sådana fall och inte en till befälet hörande polisman, vilket är fallet i den ordinära förundersökningen. Bedömningen av om åtal skall väckas fattas sedan av en annan åklagare än den som agerat som förundersökningsledare. I Sverige finns sedan 1.1.2011 en särskild enhet inom 
Rikspolisstyrelsen som ansvarar för utredningar av misstänkta brott begångna av polismän i tjänsten. Åtalsprövningen utförs av särskilda åklagare inom den landstäckande åklagarenheten Riksenheten för polismål. ${ }^{42}$

Det är långt ifrån klart hur utredningen av misstänkta brott begångna av polismän i tjänsten bör organiseras för att tillgodose objektiviteten i undersökningen. En alternativ modell hittas i Norge där förundersökningen utförs av en särskild enhet, Spesialenheten for politisaker, som blev verksam från 1.1.2005. Fråga än om en landstäckande enhet med ansvar för att undersöka ärenden som gäller huruvida anställda i polisen eller åklagarmyndigheten har begått straffbara gärningar i tjänsten. Spesialenheten är inte en del av polisen eller den ordinära åklagarmyndigheten, utan är en oavhängig organisation som är administrativt underställd Justisdepartementet och sakligt underställd Riksadvokaten. ${ }^{43}$ I flera avseenden framstår denna modell prima facie som mer ändamålsenlig, åtminstone utifrån de överväganden som här är föremål för diskussion. Å andra sidan kan då föreligga, som en följd av myndighetens från polisens fristående position, en viss risk för kompetensförlust.

\section{Till sist}

Sammanfattningsvis kan alltså konstateras att objektivitetsprincipen utgör ett centralt fundament för all polisiär verksamhet, både för de preventivt och repressivt relaterade funktionerna, i Finland, Norge och Sverige. Även om dess betydelse i utgångspunkten är rätt klar är den samtidigt en ganska diffus företeelse vars rättsliga utsträckning inte riktigt är klart fastställd. Särskilt förhållandet mellan den förvaltningsrättsliga och straffprocessuella objektivitetsprincipen synes något oklar. Mot denna bakgrund framstår rättsvetenskapliga insatser på detta område som väl motiverade.

1 Se Johan Boucht, Polisiär våldsanvändning. En straff- och offentligrättslig undersökning (2011, s. $19-20,94$.

2 Här kan nämnas några av de nordiska bidrag som under det senaste decenniet har kommit till i de nordiska landenna. Timo Loman: Poliisin oikeudesta käyttää voimakeinoja (1997), Ingrid Helmius: Polisens rättsliga befogenheter vid spaning (2000), Annika Norée: Laga befogenhet. Om polisens rätt att använda våld (2001), Roald Hopsnes, "Provokasjon som politimetode", Jussens venner (2003), s. 62-130, Annika Norée: Polisens rätt att bruka skjutvapen (2004), Thomas Elholm, Politiets brug av skydevåben - juridiske aspekter, 2003, Tor-Geir Myhrer: Som sista utvei. Om politiets anvending av skytevåpen (2005), Johan Boucht: "Om polisens rätt använda maktmedel och dess relation till nödvärn, Tidskrift utgiven av Juridiska Föreningen i Finland (2006), s. 517-523, Boucht 2011. Härutöver bör även nämnas de grundläggande läroböcker i polisrätt som förekommer: i Danmark Ib Henricsson, Politiret (2 utg. 2010), i Finland Klaus Helminen - Matti Kuusimäki - Markku Salminen, Polisrätt (2001) och i Norge Ragnar Auglend 
- Henry John Mæland - Knut Røsandhaug, Politirett (2 utg. 2004). Från Sverige bör även nämnas Nils-Olof Berggren - Johan Munck, Polislagen. En kommentar (2009).

3 Ibland talas om objektivitetskravet istället för objektivitetsprincipen. Man kan därför fråga sig om objektivitetsprincipen är just en princip eller om den istället bör uppfattas som ett normativt krav. Frågan knyter an till diskussionen om regler och principer. Man kan anse att objektivitetsprincipen till de delar den erhållit författningsstatus, och under förutsättning att dess modala term motsvaras av "skall", närmast har fătt regelkaraktär (t.ex. proportionalitetskravet i PL 8 §). Objektivitetsprincipens författningsinnehåll (på ytnivån) behöver däremot inte vara identiskt med dess innebörd som allmän rättsprincip (se Kaarlo Tuori, "Om rättssäkerhet och sociala rättigheter (samt mycket annat)", Tidsskrift for Rettsvitenskap (2003), s. 362). Man kan säga att till den del som objektivitetsprincipen är kodifierad och då har formulerats i skall-form så föreligger alltså mycket starka skäl för att tillämpa den. Härigenom kan det vara legitimt att tala om objektivitetskravet. Till den del som något element av objektivitetsprincipen inte erhållit något uttryck på författningsnivå, men preciseringen ändå kan etableras som en allmän rättsprincip, så föreligger istället goda skäl att följa principen. I dessa fall är det närmast fråga om objektivitet som princip som avses. Se härom Boucht 2011, s. 95-98 för ett liknande resonemang om legalitetsprincipen. Eftersom presumtionen är att innebörden av behovet av objektivitet (prima facie) som ett i lagstiftningen framträdande krav och som en allmän rättsprincip är likartade används begreppen i det följande parallellt.

4 Se t. ex. Johan Boucht, "De nordiska juristmötena och rättsgemenskapen i Norden", Defensor Legis (1999), s. 748.

5 Dansk rätt inkluderas inte, även om detta, inte minst ur ett nordiskt perspektiv, kunde befinnas motiverbart. Men en avgränsning bör i något skede göras. Det är prima facie oklart hur mycket mervärde ett inkluderande av dansk rätt skulle medföra för undersökningen. För det andra är avgränsningen gjord utifrån författarens personliga "anknytningar". Jag utgår från presumtionen att sannolikheten att framgångsrikt genomföra en komparation ökar märkbart om författaren också har ett "internt" betraktelseperspektiv på den rätt han avser att studera. Mina personliga "anknytningar" är att jag erhållit juristutbildning i Finland, disputerat för juris doktorsgrad i Sverige och är bosatt och verksam i Norge.

6 Den polisiära verksamheten delas vedertaget in i preventiv verksamhet, som avser förebyggande av brott och repressiv verksamhet, som avser utredande av redan begångna brott. Denna indelning är förvisso inte helt vattentät, eftersom t.ex. även den preventiva verksamheten innehåller repressiva drag. I detta sammanhang saknas dock anledning att frångå distinktionen.

7 Se härom även Rachlew 2009, s. i-iii. Även Tor-Aksel Busch, "Reaktiv kriminalitetsbekjempelse i 2020", Tidsskrift for Strafferett, s. 346.

8 Fritz Moen og norsk strafferettspleie, Utredning fra et utvalg oppnevnt ved kongelig resolusjon av 8. September 2006, NOU 2007:7. Fritz Moen-fallet var inte det första rättsfall som kom att granskas av en officiell utredning. Här kan t.ex. även nämnas det s.k. Liland-fallet. Se härom i Lilandsaken, NOU 1996:15.

9 NOU 2007:7, s. 319.

10 NOU 2007:7, s. 321.

11 NOU 2007:7, s. 324-326.

12 Angående Moens felaktiga erkännanden pekade kommissionen på att det var sannolikt att de fann sin grund i och kunde betecknas som, för det första, s.k. kapitulerande falskt erkännande som en reaktion mot press i förhörssituationen, för det andra s.k. internaliserande falskt erkännande, dvs. att den misstänkte faktiskt tror att han är skyldig eftersom förhöret har framkallat falska minnen, och för det tredje, s.k. frivilligt falskt erkännande som baserade, sig på den misstänktes behov av uppmärksamhet. Se NOU 2007:7, s. 316.

13 Redogörelsen bygger på uppgifter publicerade i media, huvudsakligen i Dagens Nyheter. Man 
kan f.ö. notera uppenbara likheter med Moen-fallet. Om bl.a. de i resningsansökningarna anförda påståendena är korrekta, så torde sannolikt delar av det som kommissionen pekar på i Moen-fallet även gälla Quick-fallet.

14 Anhöriga till två av mordoffren anmälde ärendet till justitiekansler 17.11.2006 angående brister i förundersökningen, bl.a. att förhörsledaren hade ställt ledande frågor till Quick, att gällande regler för rekonstruktion/vallning på brottsplatserna har inte följts, att rekonstruktionerna varit "riggade", och att förhörsledaren förmått Quick att ändra uppgifter som har lämnats vid tidigare förhör. Anmälan åtföljdes av en rättsutredning (55 s.) utförd av en advokat där slutsatsen var att brottsutredningarna tillrättalagts på ett sätt som fătt Thomas Quick att erkänna. JK fann emellertid att domarna var "i det stora hela mycket gedigna och välmotiverade". Beslut 28.11.2006 Dnr 7449-06-21 angående anmälan om allvarliga brister i förundersökningar angående mord m.m. Se även Göran Lambertz, DN debatt 3.12.2006.

15 Psykiatrikern Ulf Åsgård i DN 17.12.2009.

16 DN 2.2.2009.

17 Som en konsekvens av underlåtelsen kom att utredas huruvida polis eller åklagare gjort sig skyldiga till tjänstefel (DN 10.2.2009).

18 DN 14.6.2006.

19 Han uppgav härvid detaljer som inte varit officiella. Skälet att han tog kontakt med polisen var att han hört att två personer dömts för rånet i Finland.

20 Det kan noteras att de finska reglerna om konfrontation har ändrats efter detta rättsfall. Numera regleras konfrontation i förundersökningslagen 38 a $§(2003 / 645)$. Fallet kan dock fungera som en exemplifiering på brister som kan förekomma.

21 Med rättssäkerhet avses här i första hand en strävan att genom rättsnormer åstadkomma ordning, stadga och säkerhet i den sociala gemenskapen genom att dels skapa tillräckligt klara och informativa handlingsmönster, dels optimera förutsebarhet och motverka godtycke i den statliga maktutövningen (se Lars-Erik Taxell, Rätt och demokrati, 1976, s. 11-12; även Boucht 2011, s. 19-20). Man kan alltså säga att rättssäkerhet innebär att inte utsättas för godtycke med avseende på rätten. Enligt Åke Frändberg, Rättsordningens idé. En antologi i allmän rättslära, (2005), s. 256-261 kan detta ske p.g.a. rättsbrist (brist på rättslig reglering), rättspervertering (myndigheterna bryr sig inte om den reglering som finns) och rättsmanipulering (att lagar ständigt ändras eller ändras med kort varsel). Se även Nils Jareborg, Straffättsideologiska fragment, Iustus förlag 1992, s. 80-83, Håkan Gustafsson, Rättens polyvalens. En rättsvetenskaplig studie av sociala rättigheter och rättssäkerhet, (2002), s. 305-306. Jfr t.ex. Alexander Peczenik, Vad är rätt?, Norstedts 1995, s. 94.

22 Se t.ex. Dan Frände, Den straffrättsliga legalitetsprincipen (1989), Trine Baumbach, Den strafferetlige legalitetsprincip. Hjemmel og fortolkning (2008).

23 Se t.ex. Asbjørn Strandbakken: Uskyldspresumsjonen. In dubio pro reo (2003) för en omfattande analys.

24 Se Thomas Bull, "Objektivitetsprincipen", i Lena Marcusson (red.), Offentligrättsliga principer, Iustus förlag 2006, s. 77-78. Se även Boucht 2011, s. 252.

25 Se även Ulf Stridbeck - Pär Anders Granhag, Legal procedures in the Nordic countries and in the USA: A comparative overview, in P.A. Granhag (ed.), Forensic Psychology in Context. Nordic and international approaches, Willan publications 2010, s. 14-32

26 Beträffande norsk rätt, se t.ex. Fritz Moen og norsk strafferettspleie, NOU 2007:7, s. 94-95, Johs. Andenæs, Norsk straffeprosess I, 4 utg. (2008), s. 257, Jo Hov, Rettergang II. Straffeprocess (1999), s. 166, Steinar Fredriksen, Innføring i straffeprosess. 2 ed. (2009), s. 109. Beträffande svensk rätt, see t.ex. Thomas Bring - Christian Diesen, Förundersökning, 4 uppl. (2009), s. 67, 74-75. För finsk rätt, se Klaus Helminen - Kari Lehtola - Pertti Virolainen, Förundersökning och tvångsmedel (2004), s. 82-83. 
27 Se Helminen et al. 2004, s. 83, Fredriksen 2009, s. 109.

28 Man kan förstås fråga sig vilken typ av sanning som i detta skede eftersträvas, en procedurell, eller formell, sanning utgående endast från processmaterialet eller en materiell sanning utifrån vad som verkligen har hänt. Ofta anses domstolarna tillämpa den materiella sanningens princip (se t.ex. Hans Gammeltoft-Hansen, Strafferetspleje, 1998, s. 66). Förvisso kan man, som Lindblom, anse att den materiella sanningen är lika svår att uppnå som att nå fram "till regnbågens fot" och att den materiella sanningsprincipen är modifierad genom bl.a. genom bevisförbud, bundenhet vid åklagarens gärningsbeskrivning, begränsningar i resningsinstitutet men framförallt oskuldspresumtionen och straffprocessens höga beviskrav (se Per Henrik Lindblom, "Straffprocessens samhällsfunktioner", i Festskrift til Hans Gammeltoft-Hansen, 2004, s. 416-417). Av dessa anledningar kan åtminstone vissa friande domar antas vara materiellt oriktiga. Man kan följaktligen säga att den sanning som domstolarna utgår från de facto är procedurell, även om ambitionen är att utröna vad som verkligen hänt. En dylik procedurell sanning kan dock, med beaktande av den funktion som förundersökningen har, hävdas vara otillräcklig för polisen eftersom deras procedurella sanning är förhållandevis öppen (se härom "Demlan Oikeusmuha-projektin raportti. Pankkiryöstö Turussa 20.4.1994. Asian tutkinta ja oikeusprosessi”, Oikeus 2005, s. 37). Samtidigt kan förstås sägas att man med det materiella sanningsbegreppet avse att det därför främst är den fällande domen som skall vara materiellt riktig (se Bengt Lindell - Hans Eklund - Petter Asp Torbjörn Andersson, Straffprocessen, 2005, s. 22).

29 Om förhållandet mellan den formella och den materiella legalitetsprincipen, se Boucht 2011, s. 101-104.

30 Se NOU 2007:7, s. 95. Se även Ulf Stridbeck, "Holder forklaringen for domfellelse? - Thomas Quick-sakene", i Christoffer Wong (red.), Festskrift Per Ole Träskman (2011), s. 457-465, som mot bakgrund av amerikansk rättspsykologisk forskning undersökt trovärdigheten i Quickerkännandena. Enligt nämnda forskning bör medgivanden bedömas enligt coverage (täckning), coherence (sammanhang), consistency (sammanhang) plausibility (sannolikhet) och completeness (fullständighet), samt unigueness (originalitet). Härutöver kan enligt Stridbeck även ett fjärde moment nämnas, dvs. värdering av kronologin.

31 Helminen et al. 2004, s. 83.

32 Se Klaus Helminen - Matti Kuusimäki - Markku Salminen, Polisrätt, Kauppakaari 2000, s. 74 75; och Ragnar Auglend - Henry John Mæland - Knut Røsandhaug, Politirett, 2. uppl., Gyldendal 2004, s. 420.

33 Se Erik Sjöholm, När och hur får polisen ingripa. Polisrättens allmänna grunder, 2 uppl. (1978), s. 100, Bull 2006, s. 71-105, Boucht 2011, s. 252-253.

34 En diskussion av objektivitetskravets innehåll, de krav det uppställer samt hur dessa konkretiseras i det praktiska polisarbetet, särskilt beträffande förundersökningen, synes förutsätta att vissa delfrågor ställs, bl.a. huruvida en förundersökning alls bör inledas (dvs. kraven för inledande av förundersökning), vilka frågor som skall undersökas och hur undersökningen bör genomföras.

35 Se Vilhelm Aubert, Om straffens sosiale funksjon, 4 ed. (1979), s. 91-108, särskilt 96-103, Johs. Andenæs, Avhandlinger og foredrag (1962), s. 172-173. Vagn Greve, "Social klasse og straff. Et diskussionsoplæg”, Fuldmaegtigen (1972), s. 101, pekar i sin analys på sannolikheten av social ojämställdhet i förundersökningen som en följd av att polisen är påverkad av allmänna fördomar beträffande t.ex. kriminellas utseende och uppträdande, och menar därför att hög social status utgör ett gott skydd. Samtidigt bör man givetvis komma ihåg att alla likartade fall inte fullt ut kan behandlas helt identiskt.

36 Se t.ex. Janatuinen v. Finland, appl. 28552/05, 8.12.2009, para. 44, där domstolen fann att art. 6(3) innefattar: "the opportunity to acquaint himself, for the purposes of preparing his defence, with the results of investigations carried out throughout the proceedings ... Failure to disclose to the defence material evidence, which contains such particulars which could enable the accused 
to exonerate himself or have his sentence reduced, would constitute a refusal of facilities necessary for the preparation of the defence, and therefore a violation of the right guaranteed in Article $6 \S 3$ (b) of the Convention”. Beträffande denna fråga i ett komparativt perspektiv, se Paulina Tallroth, Informationsrechte des Beschuldigten im Vorverfahren. Die Verwirklichung prozessualer Garantien in Deutschland und den nordischen Ländern unter Berücksichtigung der EMRK (2004); beträffande rätten till information, se särskilt s. 111-143, 259-261.

37 Se Asbjørn Rachlew, Justisfeil ved politiets etterforskning, noen eksempler og forskningsbaserte mottiltak (2009). Se även Svein Magnussen, Annika Melinder, Ulf Stridbeck, Abid Q. Raja, "Beliefs About Factors Affecting the Reliability of Eyewitness Testimony: A Comparison of Judges, Jurors and the General Public", Applied Cognitive Psychology (2009), s. 122-133. Se även Demlan Oikeusmurha-projektin raportti 2b/2005, s. 40.

38 För ett konkret exempel, se Gisli H. Gudjonsson, "Drap i Norge: Falsk tro som ledet til falsk tilståelse", Tidsskrift for Strafferett (2004), s. 305-306. Se även NOU 2007:7, s. 325.

39 Se NOU 2007:7, s. 325, 120-121.

40 För en terminologisk diskussion beträffande förhållandet mellan "justitiemord" och "justitiefel" se Rachlew 2009, s. 2-6.

41 Se härom http://www.om.fi/text/Etusivu/Valmisteilla/Kehittamishankkeita/1266333402011.

42 Beträffande situationen i Finland kan hänvisas till Förstärkt granskning av polis och åklagare, SOU 2003:41, s. 227-230, Summa summarum, SOU 2007:5, s. 127-129. För svensk rätt, se SOU 2003:41, s. 117-125, SOU 2007:5, s. 59-68. Även Dennis Töllborg, Uppdraget! En utredning beställd av Polismyndigheten i Västa Götaland, 15.12 2010, s. 47-53.

43 Se Auglend et al. 2004, s. 1017-1033, särskilt s. 1021-1024 beträffande den s.k. SEFO-modellen, som avslutades 2004. Beträffande kritiken mot SEFO-modellen, se Ot.prp. nr. 96 (2002-2003), s. 8-11. Beträffande den rådande modellen, se Ot.prp. nr. 96 (2002-2003), s. 19-25, NOU 2009:12 ("Et ansvarlig politi. Åpenhet, kontroll og læring"), s. 62-94. 